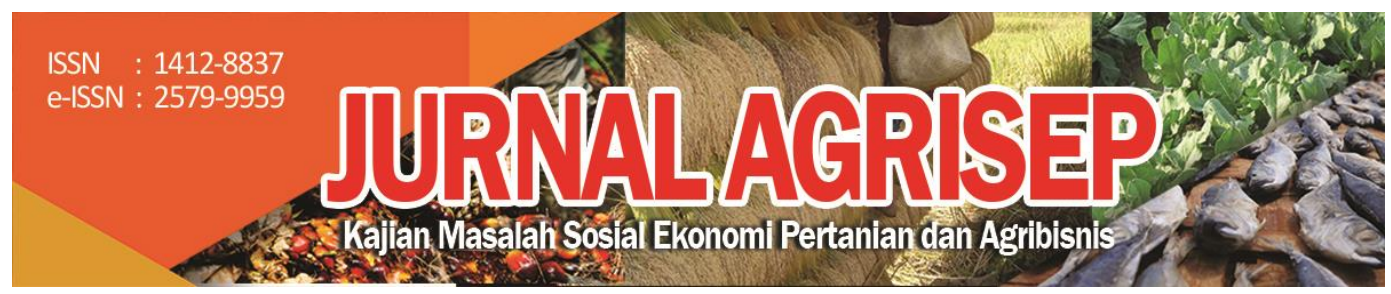

DOI: 10.31186/jagrisep.19.2.433-446

\title{
Smartphone Adoption on Fruit Marketing Communication: a Traders Perception
}

\author{
Heri Akhmadi1 \\ 1),2) Department of Agribusiness Universitas Muhammadiyah Yogyakarta \\ Email: heriakhmadi@umy.ac.id
}

\begin{abstract}
Smartphone is one of the information technology devices that widely used by traders in marketing activities. Aside from being a communication tool, traders also utilize smartphones to obtain market information and communicate about products and services to consumers. This study aims to analyze profile and perceptions of fruit traders in using smartphones as a marketing communication tool. This research employed quantitative method and descriptive analysis using five point Likert scale to examine the perception of fruit traders in Yogyakarta City. The results revealed that traders adopted smartphones on fruit marketing communication due to it perceived to provide a relative advantage, with a high level of ease of use, visible benefits, and low complexity and risk. Furthermore, Samsung, Telkomsel, and WhatsApp were brands of smartphones, telecommunications providers, and social media applications mostly chose by traders.
\end{abstract}

Keywords: Digital marketing, Technology adoption reasons, Technology profile

\section{ABSTRAK}

Telepon pintar atau smartphone merupakan salah satu perangkat teknologi informasi yang saat ini banyak digunakan oleh pedagang dalam kegiatan pemasaran. Selain sebagai media komunikasi, smartphone juga digunakan oleh pedagang untuk mendapatkan informasi pasar dan mengomunikasikan produk dan jasanya ke konsumen. Penelitian ini bertujuan untuk menganalisis profil dan persepsi pedagang buah dalam menggunakan smartphone sebagai media komunikasi pemasaran buah-buahan. Penelitian ini dilaksanakan dengan metode kuantitatif dengan analisis deskriptif menggunakan lima poin skala Likert untuk menganalisis persepsi pedagang buah di Kota Yogyakarta. Hasil penelitian menunjukkan bahwa pedagang menggunakan smartphone dalam kegiatan pemasaran buah-buahan karena dipersepsikan dapat memberikan keuntungan relatif dengan tingkat kemudahan penggunaan yang tinggi, bermanfaat 
secara nyata dengan resiko dan kompleksitas penggunaan yang rendah. Lain dari pada itu, Samsung, Telkomsel dan WhatsApp merupakan merk smartphone, provider telekomunikasi dan aplikasi yang paling banyak dipilih pedagang.

Kata Kunci: Alasan Adopsi Teknologi, Pemasaran Digital, Profile Teknologi

\section{INTRODUCTION}

Fruit is an agricultural product which showing an increasing trend in demand recently. Apart from being caused by the rise of population growth, this increase in demand of fruit is also due to the increased of per capita income (Miranti \& Syaukat, 2016), changes in modern healthy diet (Morgan et al., 2016) and awareness to consume of fruit (Korry, Yulianti, \& Yunita, 2017).

In Indonesia, fulfillment of fruit demand comes from domestic production and also imports. Data from the Indonesian Ministry of Trade reveal that fruit imports during the 2016 period amounted to USD 848.1 million. It increased by around $27.27 \%$ from the previous period in 2015 of USD 666.4 million. The import of vegetables also experienced a significant increase in 2016, amounting to USD 695.9 million, increasing by $24.7 \%$ from the previous period of 2015 of USD 658.1 million (Kemendag, 2018).

The increasing supply of imported fruit is undoubtedly a challenge for the marketing and production of domestic fruit (Niculae \& Costaiche, 2016). Moreover, agricultural product such as fruit is also facing another challenge, namely the development of information and communication technology (ICT) especially on the readiness of traders on the adoption of ICT on marketing activities (Nugroho, Susilo, Fajar, \& Rahmawati, 2018) and several technical barriers on using ICT devices (Rumanyika \& Tedre, 2019). ICT has penetrated various sectors of life at such rapid speeds. Starting from telecommunications as the primary sector, it continues to other sectors such as industry, trade, education, and recently transportation. Although the application of information technology in the fruit marketing is not as developed as other sectors such as transportation, however in the future, the effect may develop as well. ICT has a positive influence on the marketing of agricultural products (Akhmadi, 2018). It is based on the reason that with the existence of information technology, market participants (traders) can conveniently obtain market information, both product and customer information, facilitate the transaction process of goods, and reduce costs (Pandey \& Pandey, 2018).

One of the rapid information and communication technologies is the use of smartphones (Chen, Liu, \& Dai, 2013) (Haug et al., 2015). Smartphones are information technology devices having not only the basic function of calling and sending messages but also other additional features providing convenience and facilities for users to communicate. One essential feature of smartphone is the internet connectivity and multiple features provide by this device. 
The use of smartphones by Indonesian people is classified as massive, a survey of the Indonesian Internet Service Providers Association (APJII) in 2018 stated that there were $64,8 \%$ out of 264,16 million Indonesian population as internet user. Among the internet user in Indonesia, 93,9\% of them were used smartphone as ICT devices to access the internet. Smartphone is the most favourite devices to access the internet compare to tablet $(85,2 \%)$, personal computer $(68,9 \%)$ and laptop (56,6\%) (APJII, 2018). Furthermore, according to the Ministry of Communication and Information, in 2018, there will approximately 100 million active smartphone users in Indonesia - making Indonesia the fourth largest country in the world in the use of smartphones after China, India, and United States of America (Kominfo, 2015).

The high use of smartphones is indeed very promising for the future of information disclosure and internet access in Indonesia. Especially if it can be used for the advancement of the agricultural sector, specifically in the aspect of marketing agricultural products where marketing activities of agricultural products will benefit a lot if they are able to develop and optimize the benefits of smartphones for trading activities (Kelly, Vandevijvere, Freeman, \& Jenkin, 2015). Fruit marketing, for example, is one of the agricultural products that have a perishable characteristic. Rapid management of fruit supply chain could reduce the impact of losses on this product (Porat, Lichter, Terry, Harker, \& Buzby, 2018). Furthermore, by using information technology on marketing, such as smartphones, it may improve performance in product information management. Another benefit that might be obtained in the use of smartphones is the ease of getting customer access (Grewal, Ahlbom, Beitelspacher, Noble, \& Jens, 2018).

However, although smartphone usage and ownership are relatively high, their use for marketing communication practices and mobile shoping is relatively low (Kumar \& Mukherjee, 2013). Previous research showed that the high number of smartphone ownership is not proportional to their use for marketing activities, which is low due to several barriers on mobile marketing application (Chen et al., 2013), (Rumanyika \& Tedre, 2019). Most traders tend to use them to access information and social media applications (Mramba, Apiola, Kolog, \& Sutinen, 2016). Therefore, research on this issue is still limited. The use of smartphones in fruit marketing activities is an effort expected to provide positive results for traders in running their business. By using information and communication technology, it is expected that it will improve the ease of access to information, effectiveness in product management, expand consumer coverage, and ultimately increase merchant profits.

This study aims to determine profile of fruit traders in the use of smartphones in fruit marketing activities and analyze their perceptions regarding the use of smartphones as fruit marketing communication media. Research on traders' perceptions in the use of smartphones in fruit marketing 
activities is essential to be carried out as information material for the application of this technology device in fruit marketing. Therefore this research expected to provide insight into the behaviour of traders on the use of smartphone on fruit marketing communication.

\section{RESEARCH METHOD}

This research was carried out in Yogyakarta City between February and March 2019. Yogyakarta is one of the regions with the highest per capita fruit consumption in Indonesia (WFP, 2017). As the provincial capital city, it is also among the highest internet users compared to a rural area with smartphones as the most useful communication hardware (APJII, 2018). The respondents of this study were fruit traders, precisely at Giwangan Central Fruit Market. It was chosen because it is the largest market in Yogyakarta City.

The respondents of the study were taken using a census method were all fruit wholesalers in Giwangan Central Fruit Markets participated in the interview. Census survey is the best method to obtain demographic and personal characteristic of respondents (Ponto, 2015). According to data from the Yogyakarta City Trade Service, there were 73 fruit traders registered in Giwangan Fruit Market Office in 2018. However, after a field visit and based on research criteria, there were only 47 traders who were willing and fulfilled the criteria (others do not trade anymore, died, or had several shops). Therefore, the total number of respondents was 47 traders.

This research is a survey research using a descriptive-analytical method. Survey research is carried out by conducting structured interviews with respondents selected using questionnaires to obtain the facts, opinions, and behavior of respondents (McDaniel \& Gates, 2013). The descriptive method is a technique to examine the status of a group, object, condition, or event in the present in order to get a systematic and accurate description of the facts and phenomena under study (Nazir, 2014).

Likert scale was employed to examine the perception of traders on adoption of smartphone in marketing communication. The scale which was developed by Rensis Likert (Likert, 1932) is generally used method for measure attitude (Ningsih \& Cahyadinata, 2017), opinion and perception (Bishop \& Herron, 2015). A five point Likert scale consist of 5 degree of agreement from the highest score 5 to the lowest 1 are Strongly Agree (SA), Agree (A), Neither Agree nor Disagree (N), Disagree (D) and Strongly Disagree (SD)

Furthermore, perception of trader was measured using class interval formula (Diani, Ambarawati, \& Ustriyana, 2017). The detail of the formula is as follows:

$$
\mathrm{i}=\frac{\text { (maximum score }- \text { minimum score })}{\text { number of category }}
$$




$$
i=\frac{(5-1)}{5}=0,2
$$

i: interval class

Based on the formula, a range of measurement scale of traders perception on variable that influence the adoption of smartphones in fruit marketing communication is obtained. The detail of perception measurement scale is presented on Table 1.

Table 1. Perception Measurement Scale Respons

\begin{tabular}{lc}
\hline \multicolumn{1}{c}{ Category of Perception } & Average Score \\
\hline Very High & $>4.2-5$ \\
High & $>3.4-4.2$ \\
Moderate & $>2.6-3.4$ \\
Low & $>1.8-2.6$ \\
Very Low & $1-1.8$ \\
\hline
\end{tabular}

Source: Diani, Ambarawati, \& Ustriyana, 2017

\section{RESULTS AND DISCUSSION}

\section{Characteristics of Respondents}

Respondents of this study were all fruit wholesalers at Giwangan Fruit Central Market in Yogyakarta City. Among 73 traders registered at Giwangan Central Market Office, there were only 47 fruit traders who were willing and fulfilling the requirements to become respondents. In addition, some traders have more than one shop but in the name of their employees and are registered under different names. Some traders have also moved or are no longer trading in the Giwangan Market.

There are four variables used to describe the characteristics of respondents in this study, namely age, gender, education level, and trading experience. These variable are The detail of demographic characteristic of fruit traders in Giwangan Central Market is presented in Table 2.

Table 2 shows that the majority of fruit traders were young people between 19-35 years old, amounting to 23 people or $55.8 \%$ with average 36 years old. Previous study found that younger people are more likely to use smartphone (Ma, Chan, \& Chen, 2016). The existence of these young people is a good potential because it is easy for them to adopt information technology (Abdullah \& Samah, 2017) . As for gender, men dominated this profession, namely 40 people or $85.11 \%$ of the total number of traders. The dominance of men among fruit traders in the Giwangan Central Market can be understood because the work time is quite long, and the majority of work is done at night until the early 
hours. Generally, they have started working from $11 \mathrm{pm}$ to $7 \mathrm{am}$, which may be rather heavy for women.

Table 2. Characteristics of Respondents

\begin{tabular}{|c|c|c|c|c|c|}
\hline \multirow{2}{*}{ No } & \multirow{2}{*}{ Variable } & \multirow{2}{*}{ Range } & \multicolumn{3}{|c|}{ Respondent $(\mathrm{N}=47)$} \\
\hline & & & Number & $\%$ & Mean \\
\hline \multirow{4}{*}{1} & \multirow{4}{*}{ Age (Year) } & $\leq 18$ & 0 & 0.00 & \multirow{4}{*}{36.28} \\
\hline & & $19-35$ & 26 & 55.32 & \\
\hline & & $36-55$ & 16 & 34.04 & \\
\hline & & $>56$ & 5 & 10.64 & \\
\hline \multirow{3}{*}{2} & \multirow{3}{*}{ Gender } & Male & 40 & 85.11 & \\
\hline & & Female & 7 & 14.89 & \\
\hline & & Elementary & 8 & 17.02 & \\
\hline \multirow{3}{*}{3} & \multirow{3}{*}{ Education } & Junior High School & 6 & 12.77 & \\
\hline & & Senior High School & 27 & 57.45 & \\
\hline & & Graduate & 6 & 12.77 & \\
\hline \multirow{4}{*}{4} & \multirow{4}{*}{$\begin{array}{l}\text { Trade Experience } \\
\text { (Year) }\end{array}$} & $\leq 5$ & 15 & 32 & \multirow{4}{*}{13.51} \\
\hline & & $6-10$ & 4 & 9 & \\
\hline & & $11-20$ & 18 & 38 & \\
\hline & & $>20$ & 10 & 21 & \\
\hline
\end{tabular}

Source: Primary data, calculated by the authors (2019)

Based on educational factors, as many as 27 traders or $57.45 \%$ had high school education background. There were six traders $(12.77 \%)$ who were college graduates or Bachelor/ Master. People having sufficient education tend to easily adopt technology and accept new things since education has possitive effence on smartphone adoption (Michels, Fecke, Henning, \& Oliver, 2019). Furthermore, in terms of trading experience, the majority or $59 \%$ of traders ( 28 people) had more than 10 years (mean 13.5) of experience. Even 10 of them (21\%) have been running the fruit business for more than 20 years. The duration of this experience allows them to experience various methods in product marketing, especially concerning the use of technology (Fullwood, Quinn, Kaye, \& Redding, 2017).

\section{Profile of Traders on the Use of Smartphones in Fruit Marketing}

The use of smartphones by traders in Yogyakarta City for daily activities is nothing new, but their usage in fruit marketing activities is probably still not optimal. Table 3 shows the characteristics of smartphone usage by fruit traders in Giwangan Market in Yogyakarta.

Based on Table 3, majority of fruit traders had used smartphones for 5.94 or six years, where the longest was for 10 years and the latest one since a year ago. Study showed that personal experience positively impact on smartphone adoption (Tahamtan, Pajouhanfar, Sedghi, Azad, \& Roudbari, 2017). Moreover, 
this study demonstrated that most traders as many as 42 people or $85.11 \%$ had used a mobile phone or cellphone (non internet-enable smartphone) before using smartphones. The length of usage and experience of using similar devices provides benefits in the process of adopting smartphone technology to be used in fruit marketing activities (Su, Wang, \& Yan, 2017).

Table 3. Smartphone Usage by Fruit Traders

\begin{tabular}{|c|c|c|c|c|}
\hline \multirow{2}{*}{ No } & \multirow{2}{*}{ Variable } & \multirow{2}{*}{ Respond } & \multicolumn{2}{|c|}{ Frequency $(\mathrm{N}=47)$} \\
\hline & & & Number & $\%$ \\
\hline \multirow{4}{*}{1} & \multirow{4}{*}{$\begin{array}{l}\text { Experience on using smartphone } \\
\text { (Year) }\end{array}$} & $1-2$ & 2 & 4,26 \\
\hline & & $3-5$ & 18 & 38,30 \\
\hline & & $6-10$ & 27 & 57,45 \\
\hline & & $>10$ & 0 & 0,00 \\
\hline \multirow{2}{*}{2} & \multirow{2}{*}{$\begin{array}{l}\text { Experience in using a mobile } \\
\text { phone }\end{array}$} & Yes & 42 & 85,11 \\
\hline & & No & 5 & 14,89 \\
\hline \multirow{6}{*}{3} & \multirow{6}{*}{ Smartphone Brand } & Samsung & 26 & 55,32 \\
\hline & & Oppo & 17 & 36,17 \\
\hline & & Vivo & 5 & 10,64 \\
\hline & & Lenovo & 1 & 2,13 \\
\hline & & Huawei & 2 & 4,26 \\
\hline & & Xiaomi & 4 & 8,51 \\
\hline \multirow{3}{*}{4} & \multirow{3}{*}{ Telecomunication Provider } & Tekomsel & 33 & 70 \\
\hline & & Indosat & 11 & 23 \\
\hline & & $X \mathrm{~L}$ & 15 & 32 \\
\hline \multirow{4}{*}{5} & \multirow{4}{*}{ Social Media Application } & WhatsApp & 44 & 94 \\
\hline & & Facebook & 28 & 60 \\
\hline & & Instagram & 10 & 21 \\
\hline & & LINE & 4 & 9 \\
\hline \multirow{3}{*}{6} & \multirow{3}{*}{$\begin{array}{l}\text { Monthly expenditure on } \\
\text { smartphone usage (in } \\
\text { Rupiah/IDR) }\end{array}$} & $0-100.000$ & 13 & 28 \\
\hline & & $101.000-500.000$ & 32 & 68 \\
\hline & & 501.000 - >1.000.000 & 2 & 4 \\
\hline
\end{tabular}

Source: Primary data, calculated by the authors (2019)

As for the smartphone brands used, Samsung was traders' most chosen brand having the largest number of users, namely 26 traders (55.3\%), followed by OPPO (36.17\%), Vivo (10.6\%), and the rest were Xiaomi, Huawei and Lenovo. This result inline with the survey conducted by Indonesian Internet Service Provider Association (APJII) in 2018 where Samsung is the most popular smartphone brand in Indonesia (APJII, 2018). There are several reasons that Samsung is the most widely used smartphone in Indonesia, namely from its brand image and price (Djatmiko \& Pradana, 2016), and also product quality and after sales service (Bayu, Noor, \& Diah, 2019). 
Furthermore, regarding to internet service providers brand, the majority of respondent were using Telkomsel, namely 33 traders $(70.21 \%)$, then as many as 15 people $(31.9 \%)$ utilized XL, and 11 traders $(23.4 \%)$ chose Indosat. Telkomsel a subsidiary of PT. Telkom, a state own company, is wellknown as market leader of mobile service provider in Indonesia not only from its market share (Hidayat \& Hendrawan, 2020), but also from quality of product, promotion and price (Gulliando \& Shihab, 2019).

Other variables were social media which were applications installed on smartphones. This study found that majority of traders (44 people or $94 \%$ ) used WhatsApp applications as their social media application, followed by Facebook (28 traders or $60 \%)$, Instagram $(21 \%)$ and LINE $(9 \%)$. This study underlines WhatsApp as the most popular mobile message application in Indonesia (Statista, 2019). The popularity of WhatsApp not only because this application is fun, enjoyable and exceed its function as online message application (Fernándezrobin, Yáñez, \& Mccoy, 2019), but also interm of marketing activities it can be utilized to spread information quicly to the user network (Fouad, 2017). Finally for the costs of using smartphone devices monthly, traders have different fund allocations, varying from at least IDR 75,000 per month to IDR 1,500,000 per month. While the average expenditure per month to pay for smartphone usage is IDR 262,426 .

\section{Perception of Traders on the Adoption of Smartphones on Fruit Marketing Communication}

Regarding traders' perceptions on the adoption of smartphones as a fruit marketing communication tool, this study refers to variables influencing the process of technology adoption, as explained by The Theory of Diffusion of Innovation developed by Everett M. Rogers (Rogers, 2002). There are five attributes of innovation and several indicators that proposed to shape the traders' perceptions. These five attributes consist of advantage, compatibility, observability, complexity, and risk. Furthermore, each attribute and indicator were analyzed using the average score of each attribute and indicator which are presented in Table 4.

According to Table 4, the advantage variable shown by indicators of usability, efficiency, work effectiveness, direct benefits, and economic benefits has a very high noble score average of 4.20 overall. Whilst the highest score is 4.60 for usability and the lowest of 3.87 for direct benefit indicators. This perception shows that smartphones have very high benefits, such as efficiency, effectiveness, and other economic benefits. In other words, traders may assumed that smartphones provide positive benefits for marketing activities. Therefore, they have a high tendency to adopt smartphone technology in fruit trading activities. One of the reasons that smartphone has high usability is the sophisticated features provide on this mobile device such as internet connection, 
social media application, mobile browser and other functions related to smartphone (Pal et al., 2017).

The next attribute is compatibility, which means that smartphone technology, according to the traders, matches the device used. The highest score of each attribute indicator was in the ease of use aspect of 4.21, and the lowest was on the prestige indicator of 2.23 with the overall score of 3.49 (high category). It shows that it was easy for fruit traders to use smartphone technology (since they had the experience of using similar devices before such as cellphones or mobile phones), compare to other perception on using smartphones for prestige (Ismail, 2016). It is understandable because today's smartphones are no longer considered as luxurious goods, however, it is a devices that almost everyone has it (Kamble \& Jain, 2020).

Table 4. Traders' Perception on the Adoption of Smartphone on Fruit Marketing Communication

\begin{tabular}{lllll}
\hline \multirow{2}{*}{ Variable } & & \multicolumn{1}{c}{ Average Score } \\
& & & \\
& Usefullness & 4,60 & \\
ADVANTAGE & Efficiency & 4,28 & \\
& Effectivity & 4,17 & 4.20 \\
& Immediacy & 3,87 & \\
& Economic Benefit & 4,06 & \\
& Easy to Use & 4,21 & \\
COMPATIBILITY & Consistency with previous experience & 3,15 & \multirow{2}{*}{3.49} \\
& Prestige & 2,23 & \\
& Low Cost & 3,79 & \\
OBSERVABILITY & Meet the trader need & 4,04 & \\
& Reducing Constraints & 3,96 & \\
& Saving Time & 4,17 & 4.13 \\
COMPLEXITY & Visible Benefit & 4,28 & \\
& Requires Extra Effort & 1,83 & \\
& Difficulties in Usage & 1,85 & \multirow{2}{*}{1.90} \\
RISK & Complicated Feature & 2,02 & \\
& Risk of Usage & 2,28 & \multirow{2}{*}{2.11} \\
\hline
\end{tabular}

Source: Primary data, calculated by the authors, 2019

The third attribute is observability, which sees that existing innovations or new technologies have apparent benefits. The average score of the indicators, such as benefits, was seen at 4.28 (very high), making it the highest compared to other indicators, namely the reduction of constraints and saving time. These results indicate that the use of smartphones in trading provides benefits that can be seen directly or felt by traders while reducing the obstacles in trading and 
saving time. Smartphones are proven to provide time-efficiency benefits and various other benefits for users (Lee, 2016).

Furthermore, the fourth attribute is complexity, which means the merchants' perception of the complexity of using a smartphone. Three indicators describe this variable, namely extra effort in usage, usage difficulty, and features difficult to understand. Variable complexity has a negative direction, meaning that the lower score indicates that there are no difficulties in using technology. The average score for the indicator of difficulty in usage was 1.85 (low), meaning that traders did not find it difficult to use smartphones. Perhaps a rather high level is about an elusive feature indicator with an average score of 2.02 (low). However, this value is still category as low. Therefore, despite the difficulties, it is quite easy to understand the features of smartphones. This result may because majority of traders were young adult, so they don't have too much difficulty on using smartphones. Study showed that young smartphone users tend to be longer and have no difficulty using it (Andone, Eibes, Trendafilov, Montag, \& Markowetz, 2016).

The last attribute is the risk or the perception regarding the risk of using smartphones. There are two indicators of this variable, namely, usage risk and security risk. Just like complexity variables, the risk variable also has a negative value, which means that the smaller the traders can interpret, the lower the risk of usage. Based on Table 4, the risk indicator of using smartphones has an average score of 2.28 (low), indicating that traders felt there was a risk in using smartphones at a low level. While the security risk indicator has a lower average score of 1.94 (low), therefore, it can be said that traders did not feel the security risk in using smartphones for fruit trading activities. The low of perceived risk on using smartphone on marketing activities among traders may come from their trust on technology, brand integrity and performance of service provider (Dayour, Park, \& Kimbu, 2019).

\section{CONCLUSION AND SUGGESTION}

\section{Conclusion}

Based on the results and discussion, it can be concluded that traders perceptions on the adoption of smartphones, they perceived that smartphones provided a relative advantage, with a high level of ease of use, visible benefits, and low complexity and risk on fruit marketing communication. Furthermore, Samsung, Telkomsel, and WhatsApp were brands of smartphones, telecommunications providers, and social media applications they mostly chose. 


\section{Suggestion}

These study imply a positive signal for the development of digital fruit marketing by further optimizing smartphone features and technology to support fruit marketing activities in Yogyakarta City. Policy implication of the results of this study is to encourage the government and related agencies to provide training for traders to optimize the use of smartphones in supporting marketing activities including the use of the WhatsApp application for marketing.

\section{REFERENCES}

Abdullah, F. A., \& Samah, B. A. 2017. Factors Impinging Farmers ' Use of Agriculture Technology. Asian Social Science, Vol. 9(No. 3), 120-124.

Akhmadi, H. 2018. Use of Information and Communication Technology (ICT) on Agricultural Marketing in Indonesia a Brief Literature Review. In Proceedings of the International Conference on Food, Agriculture and Natural Resources (FANRes 2018). Atlantis Press.

Andone, I., Eibes, M., Trendafilov, B., Montag, C., \& Markowetz, A. 2016. How Age and Gender Affect Smartphone Usage. In UbiComp '16: Proceedings of the 2016 ACM International Joint Conference on Pervasive and Ubiquitous Computing (pp. 9-12).

APJII. 2018. Laporan Survei Penetrasi \& Profil Perilaku Pengguna Internet Indonesia 2018 (Survey Report: Penetrarion \& Behaviour Profile of Indonesian Internet User 2018). Jakarta, Indonesia.

Bayu, R., Noor, Y. L., \& Diah, K. 2019. Analysis of The Effect of Brand Image, Product Quality and Aftersales Service on Repurchase Decision of Samsung Smartphones. Russian Journal of Agricultural and SocioEconomic Sciences, 8(92), 19-32.

Bishop, P. A., \& Herron, R. L. 2015. Use and Misuse of the Likert Item Responses and Other Ordinal Measures. International Journal of Exercise Science, 8(3), 297-302.

Chen, H., Liu, F., \& Dai, T. 2013. Chinese Consumers' Perceptions Toward Smartphone and Marketing Communication On Smartphone. International Journal of Mobile Marketing, 8(1), 38-45.

Dayour, F., Park, S., \& Kimbu, A. N. 2019. Backpackers ' perceived risks towards smartphone usage and risk reduction strategies: A mixed methods study. Tourism Management, 72(August 2018), 52-68.

Diani, N. M. I., Ambarawati, I. G. A. A., \& Ustriyana, I. N. G. 2017. Manajemen Logistik dan Persepsi Konsumen Lembaga terhadap Pemasaran Asparagus oleh Koperasi Tani Mertanadi di Desa Plaga Kecamatan Petang Kabupaten Badung. E-Jurnal Agribisnis Dan Agrowisata, 6(2), 291-300 
Djatmiko, T., \& Pradana, R. 2016. Brand image and product price; Its impact for Samsung smartphone purchasing decision. In 3rd Global Conference on Business and Social Science (Vol. 219, pp. 221-227). Kuala Lumpur, Malaysia: Procedia - Social and Behavioral Sciences.

Fernández-robin, C., Yáñez, D., \& Mccoy, S. 2019. Intention to Use WhatsApp. In Artificial Intelligence - Scope and Limitations (pp. 1-14).

Fouad, N. 2017. Viral marketing effect on digital knowledge acquisition: WhatsApp as a model. Alexandria: The Journal of National and International Library and Information Issues, 27(1).

Fullwood, C., Quinn, S., Kaye, L. K., \& Redding, C. 2017. My Virtual friend: A qualitative analysis of the attitudes and experiences of Smartphone users: Implications for Smartphone attachment. Computers in Human Behavior, 75, 347-355.

Grewal, D., Ahlbom, C.-P., Beitelspacher, L., Noble, S. M., \& Jens, N. 2018. InStore Mobile Phone Use and Customer ShoppingBehavior: Evidence from the Field. Journal of Marketing, July, 1-57.

Gulliando, D., \& Shihab, M. S. 2019. The Effect of Product Quality , Price and Promotion on the Purchase Decision of Telkomsel Service Products. International Journal of Innovative Science and Research Technology, 4(9), 419-425.

Haug, S., Paz Castro, R., Kwon, M., Filler, A., Kowatsch, T., \& Schaub, M. P. (2015). Smartphone use and smartphone addiction among young people in Switzerland. Journal of Behavioral Addictions, 4(4), 299-307.

Hidayat, E. A., \& Hendrawan, R. (2020). Should Telkom Do IPO for Telkomsel ? In Proceedings of the 2nd International Conference on Inclusive Business in the Changing World (ICIB 2019) (pp. 337-347).

Ismail, H. A. (2016). Intention to Use Smartphone through Perceived Compatibility, Perceived Usefulness, and Perceived Ease of Use. JDM Jurnal Dinamika Manajemen, 7(16), 1-10.

Kamble, S. C., \& Jain, S. (2020). A Study on Usage of Smart Phone among youngsters and Its Marketing Implications with Special Reference To Pune. Studies in Indian Place Names, 40(60), 6224-6243.

Kelly, B., Vandevijvere, S., Freeman, B., \& Jenkin, G. 2015. New Media but Same Old Tricks: Food Marketing to Children in the Digital Age. Current Obesity Reports, 4(January 2015), 37-45.

Kemendag. 2018. Growth of Non-Oil and Gas Export (Commodity) Period: 20132018. Jakarta.

Kominfo. (2015). Indonesia Raksasa Teknologi Digital Asia. Retrieved from https://www.kominfo.go.id/content/detail/6095/indonesia-raksasateknologi-digital-asia/0/sorotan_media 
Korry, P. D. P., Yulianti, N. M. D. R., \& Yunita, P. I. (2017). Increase the Attractiveness of Local Fruits to Buying Intention of Hedonic Consumers in Bali. International Research Journal of Management, IT and Social Sciences, 4(6), 10-16.

Kumar, A., \& Mukherjee, A. (2013). Shop While You Talk: Determinants of Purchase Intentions Through a Mobile Device. International Journal of Mobile Marketing, 8(1).

Lee, S. (2016). Quantifying the Benefits of Smartphone Adoption: Digital Device Substitution and Digital Consumption Expansion. In Stanford University and the Korea Information Society Development Institute (KISDI) (p. 58). Stanford University Department of Economics.

Likert, R. (1932). A technique for the measurement of attitudes. Archives of Psychology, 22(140), 5-.

Ma, Q., Chan, A. H. S., \& Chen, K. (2016). Personal and other factors affecting acceptance of smartphone technology by older Chinese adults. Applied Ergonomics, 54, 62-71.

McDaniel, C., \& Gates, R. (2013). Marketing Research. Marketing Research Ninth Edition (Ninth Edit). John Wiley \& Sons Singapore Pte. Ltd.

Michels, M., Fecke, W., Henning, J., \& Oliver, F. (2019). Smartphone adoption and use in agriculture: empirical evidence from Germany. Precision Agriculture, 21, 403-425.

Miranti, A., \& Syaukat, Y. (2016). Pola Konsumsi Pangan Rumah Tangga di Provinsi Jawa Barat (Household Food Consumption Patterns in West Java Province). Jurnal Agro Ekonomi, 34(1), 67-80.

Morgan, E. H., Vatucawaqa, P., Snowdon, W., Worsley, A., Dangour, A. D., \& Lock, K. (2016). Factors influencing fruit and vegetable intake among urban Fijians: A qualitative study. Journal Appetite, 101, 114-118.

Mramba, N., Apiola, M., Kolog, E. A., \& Sutinen, E. (2016). Technology for street traders in Tanzania: A design science research approach. African Journal of Science, Technology, Innovation and Development, 8(1), 121-133.

Nazir, M. (2014). Metode Penelitian (Research Method) (9th ed.). Jakarta: Ghalia Indonesia.

Niculae, I., \& Costaiche, G. M. (2016). Study on The Influence of Import and Export of Fruit in Romania on Economic Indicators. Scientific Papers Series Management, Economic Engineering in Agriculture and Rural Development, 16(1), 343-354.

Ningsih, F. S., \& Cahyadinata, I. (2017). The Fisherman Perception Study on Fishery Policy in Bengkulu City. Jurnal AGRISEP, 16(2), 133-144.

Nugroho, M. A., Susilo, A. Z., Fajar, M. A., \& Rahmawati, D. (2018). Exploratory Study of SMEs Technology Adoption Readiness Factors. In I. 2017 4th 
Information Systems International Conference 2017 (Ed.), Procedia Computer Science (Vol. 124, pp. 329-336). Bali, Indonesia: Elsevier B.V.

Pal, J., Viswanathan, A., Chandra, P., Nazareth, A., Kameshwaran, V., Subramonyam, H., ... Modhrain, S. O. (2017). Agency in Assistive Technology Adoption: Visual Impairment and Smartphone Use in Bangalore. In Proceedings of the 2017 CHI Conference on Human Factors in Computing Systems (pp. 5929-5940).

Pandey, S., \& Pandey, M. (2018). Enhancing Efficiency of Agri-input Marketing through ICT Applications. Journal of Agroecology and Natural Resource Management, 5(3), 135-137.

Ponto, J. (2015). Understanding and Evaluating Survey Research. Journal of The Advanced Practitioner Oncology, 6(2), 168-171.

Porat, R., Lichter, A., Terry, L. A., Harker, R., \& Buzby, J. (2018). Postharvest Biology and Technology Postharvest losses of fruit and vegetables during retail and in consumers ' homes : Quanti fi cations, causes, and means of prevention. Postharvest Biology and Technology, 139(February), 135-149.

Rogers, E. M. (2002). Diffusion of preventive innovations. Addictive Behaviors, 27, 989-993.

Rumanyika, J., \& Tedre, M. (2019). Mobile Technology Usage for Street Traders' Market Search in Dodoma - Urban Tanzania: An Exploratory Study. The African Journal of Information Systems, 11(4), 249-278.

Statista. (2019). Penetration of leading social networks in Indonesia as of 3rd quarter 2018. Retrieved from

https://www.statista.com/statistics/284437/indonesia-socialnetwork-penetration/

Su, P., Wang, L., \& Yan, J. (2017). Technology Analysis \& Strategic Management How users ' Internet experience affects the adoption of mobile payment: a mediation model. Technology Analysis $\mathcal{E}$ Strategic Management, 30(2), 1-12.

Tahamtan, I., Pajouhanfar, S., Sedghi, S., Azad, M., \& Roudbari, M. (2017). Factors affecting smartphone adoption for accessing information in medical settings. Health Information and Libraries Journal, 34(6), 134-145. WFP. (2017). Buletin Pemantauan Ketahanan Pangan Indonesia, Fokus Khusus: Tren Konsumsi dan Produksi Buah (Food Security Monitoring Bulletin: Special Focus: Fruit and vegetable consumption and production trends). Buletin Pemantauan Ketahanan Pangan Indonesia (Vol. 8). Jakarta.

446 | Heri Akhmadi, Muhammad Fauzan; Smartphone Adoption ... 